\title{
Land Rights Registration through Systematic Land Registration
}

\author{
Faisal Santiago ${ }^{1}$, Evita Isretno Israhadi ${ }^{2}$ \\ University of Borobudur ${ }^{1,2}$ \\ \{faisalsantiago@borobudur.ac.id ${ }^{1}$, evita_isretno@borobudur.ac.id ${ }^{2}$ \}
}

\begin{abstract}
The implementation of land registration that allows land rights holders to prove the rights to the land they control quickly, and for interested parties, such as prospective buyers and prospective creditors, to obtain the necessary information about the land that is the object of legal action to be carried out, as well as for the government to carry out land policy. This research is empirical law research, where this research is a legal research method that serves to see the law in a real sense and examine how the law works in the community.
\end{abstract}

Keywords: Land Rights; Land Registration; Systematic Registration

\section{Introduction}

Land as a gift of God Almighty is a natural resource needed by humans to meet the needs, such as farming, shelter, and making efforts. So precious is the land that a human being who is a social being will defend his land in any way.1 The founding fathers, in drafting the Constitution, pay special attention to the land. In the Constitution (Uud 1945), Regulation of the land uses the term Agrarian, which has a wider scope, namely the earth, water, and natural wealth. Not enough on that alone, the founding fathers also tried to design an umbrella of national law that regulates explicitly land.

In Indonesia, the function of land is increasing due to the increasing use of land so that the economic value also increases. The rising human need for land has consequences for the growing land problems in Indonesia. This land problem is caused by a comparison between the amount of land available and each human being's basic needs who have rare and limited properties. Article 33 paragraph (3) of the 1945 Constitution specifies that: The Earth, water, and natural wealth contained therein are controlled by the State and used to the greatest extent for the people's prosperity and welfare. Efforts in utilising and using land that is part of natural resources must therefore be implemented wisely. Land as a natural resource that cannot be renewed has an essential role in supporting national development. Consequently, it is necessary to have a regulation governing Agrarian, especially land, namely Law no. 5 of 1960 on Basic Rules of Agrarian Principles, which is often referred to by the official abbreviation of Agrarian Basic Law.

Finally, on September 24, 1960, was born Law No. 5 of 1960 on the Basic Rules of Agrarian Fundamentals or often known as the Agrarian Basic Law.2 Agrarian Basic Law brings the principles of no classification of the population as well as the politics of colonial 
law, containing the basics of equal distribution of land ownership (Land reform), social functions of land rights, as well as giving place to customary law as ordered from Article 18B paragraph (2) constitution 1945: "The State recognises and respects the unity of the indigenous legal community and its traditional rights as long as it is alive and under the development of society and the principles of the Unitary State of the Republic of Indonesia stipulated in the law". Also, the UUPA also removes the principle of the domain by giving rise to the "right to control the State" as instructed by Article 33 paragraph (3) of the 1945 Constitution: "The earth and water and natural wealth contained therein are controlled by the State and used for the greatest prosperity of the people".

One of the purposes of enacting Law No. 5 of 1960 on Basic Rules of Agrarian Principles (UUPA) is to provide guarantees of legal certainty. This goal can be realised through two efforts: the availability of written, complete and clear legal devices that are implemented consistently according to the soul and its provisions.

The implementation of land registration that allows land rights holders to prove the rights to the land they control quickly, and for interested parties, such as prospective buyers and prospective creditors, to obtain the necessary information about the land that is the object of legal action to be carried out, as well as for the government to carry out land policy.

The purpose of assuring legal certainty is in Article 19 paragraph (1) of the Agrarian Basic Law, which reads: "To ensure legal certainty by the Government held land registration in all Republic of Indonesia regions according to the provisions stipulated by government regulations." From this provision, it is understood that the Land Registry is addressed to the government as the supreme ruler of the land.

It moves from the provision mater bit lah Government Regulation No.10 the Year 1961 on Land Acquisition.3 The Government Regulation is a product of Government law to implement the provisions of Article 19 of the Agrarian Basic Law. With the Regulation, it is expected that land registration can be implemented soon to create legal certainty and reduce land disputes between landowners. However, along with the development of the times and the legal content contained in Government Regulation No. 10 of 1961 is no longer following the legal needs of the community in land registration, the issuance of Government Regulation No.24 of 1997 on Land Registration which also states that Government Regulation No.10 of 1961 is no longer valid.

Government Regulation No.24 of 1997 has a very strategic and decisive position, not only as of the implementation of the provisions of Article 19 of the Law but more than the Government Regulation becomes the backbone that supports the running of land administration as one of the programs Chess Order land and Land Law in Indonesia.

Also, Government Regulation No. 24 the Year 1997 provides an understanding of the Land Registration contained in Article 1 number 1, namely: A series of activities carried out by the government continuously, continuously and regularly, including the collection, processing, bookkeeping, and presentation and maintenance of biological data and juridical data, in the form of maps and lists, concerning land areas and units of flats, including the provision of proof of its rights to existing land areas and property rights to companies of apartments and certain rights that burden him.

Guarantees of legal certainty to be realised in the Registration of this land, including the assurance of the status of the rights listed, the confidence of the subject of righteousness, and certainty of the object of ownership. The Registration of this land produces a Certificate as proof of its rights. The opposite of land registration (Rechts Cadaster) is Fiscaal Cadaster, a land registry that aims to determine who is obliged to pay taxes on land. This land registration 
produced proof of tax payment on the ground, known as the Land and Buildings Tax Payable Tax (SPPT PBB).

The agricultural policy is part of regional Autonomy, namely delegation of central government authority to local government in terms of land. Regional Autonomy in response to demands for changes to the policy patterns of the centralised State and Government

The problems that arise are about institutions, division of duties, work procedures and other services inland. The UUPA can be implemented in full and in line with Law No. 32 of 2004 on Local Government. Based on Law No. 32 of 2004, Article 1, number 5 defines regional Autonomy as the right, authority, and obligation of autonomous regions to regulate and manage their own governmental affairs and local communities' interests following the laws regulations.

The person then utilises this condition to benefit themselves so that there is an increase in disputes. In addition to these factors, passive agencies' attitude, waiting for land rights holders who want to register the rights to their land and mentalists who are not commendable officers is the cause of the slow process of certification of land rights. But the Agrarian National Project held in Klaten District encountered many obstacles that ultimately led to the inaccuracy of the target in determining the Agrarian National Project participants.

One of the purposes of establishing the UUPA is to provide guarantees of legal certainty regarding land rights for all Indonesians. Legal certainty will be realised if land registration is held as stipulated in the provisions of Article 19 paragraph (1) of the Constitution, which specifies that: To ensure legal certainty by the government-held land registration in all regions of the Republic of Indonesia according to the provisions stipulated by government regulations. The provisions of Article 19 paragraph (1) of this LAW are intended to conduct land registration for all Indonesian people. The requirement is further stipulated in Government Regulation No. 10 of 1961 concerning Land Registration which Government Regulation then replaces No. 24 of 1997 concerning Land Registration. The definition of Land Registry is stipulated in Article 1 paragraph (1) PP No. 24 of 1997 Land Registration is a series of activities carried out by the government continuously, continuously and regularly, including the collection, processing, bookkeeping, and presentation and maintenance of biological data and juridical data, in the form of maps and lists, concerning land areas and units of flats and the rights that burden them. In addition to the above provisions, there are other provisions in the CONSTITUTION addressed to land rights holders. This is following Article 23 of the Constitution, which specifies that: Property Rights, as well as any transfer, removal and imposition of them with other rights, must be registered according to the provisions referred to in Article 19, and the Registration referred to in paragraph 1 is a powerful evidentiary tool regarding the removal of property rights and the validity of the transfer and imposition of such rights.

Based on the provision of land registration activities for the first time, the government is carried out for the first time. People who have not registered their property objects immediately register their property rights to obtain certainty and legal protection through systematic or sporadic land registration. One of the purposes of land registration is to implement a land administration order regulated in Article 3 of Government Regulation No. 24 of 1997. Then the Head of Land Office carried out land registration, one of them with an activity called Complete Systematic LandRegistration.

Many lower-middle-class people who own uncertified land do not receive the Agrarian National Project's allocation. The legalisation of land assets through the Complete Systematic Land Registration is expected that the public can register the rights to the land they own or own to have a valid legal force to reduce the occurrence of land disputes. 


\section{Methodology}

This research is empirical law research, where this research is a legal research method that serves to see the law in a real sense and examine how the law works in the community. Because in this study researching people in relationships living in the community, empirical legal research methods can be said as sociological law research. It can be noted that legal analysis is taken from the facts that exist in a society, legal entity or government entity.

\section{Result and Discussion}

\subsection{Complete Systematic Land Registration Participants}

The next stage is the determination of participants of the Complete Systematic Land Registration. The mechanism of determining participants of Systematic Land Registration is as follows:

a. According to the Pekanbaru City Land Office, the Lurah proposes a candidate for Complete Systematic Land Registration according to predetermined criteria.

b. The Head of the Klaten Regency Land Office examines and reviews the proposal.

c. The Head of the Land Office of Klaten Regency issues a Decree regarding the candidate for Participating in Complete Systematic Land Registration with due observance of the proposal from the Lurah who is known to the Camat. However, this proposal is not an absolute consideration. The Head of the Klaten Regency Land Office can decide for himself the participants of the Complete Systematic Land Registration according to the data from the results of the study conducted.

\subsection{Implementation of Land Rights Registration through Complete Systematic Land Registration}

A or the Adjudication Committee shall hold a session to examine and review the land inspection results by Committee A or the Juridical task force collectively. The land inspection hearing is attended by all members of Committee A plus village officials. The trial results shall be contained in the minutes of land inspection A or DI.201 and constitute the conclusion of Committee A. or Education which becomes the material for consideration to grant or reject the request in question.

\section{a) Announcement of Rights Recognition}

The land inspection activity is continued with the announcement of the recognition of rights carried out to fulfil the requirements as a process for systematic Complete Systematic Land Registration activities and conversion/recognition of rights in organised Complete Systematic Land Registration activities. The announcement of the award of rights for Complete Systematic Land Registration activities carried out in Cawas District, Klaten Regency, is intended to provide an opportunity for interested parties to file objections to biological data and juridical data in the context of determining rights on behalf of the applicant/participant of Complete Systematic Land Registration. The announcement includes land parcels with a list of each parcel area and data on land ownership. Suppose there is an objection at the time of the information, and based on the research, there are several errors 
regarding the results of the size of the land parcels listed on the land parcels. In that case, the map of the land parcels and the mapping results on the base map of Registration or the map of Registration shall be changed.

\section{b) Establishment of Rights}

The determination of Complete Systematic Land Registration rights in Cawas District, Klaten Regency is carried out after announcing land ownership rights has been completed. For the validity of land ownership data, the announcement of rights is carried out for 30 (thirty) days. For customary land whose documents are complete and meet the requirements, the title is determined through conversion. Traditional land whose evidentiary documents are missing, incomplete, or questionable, the rights are selected through recognising rights. For customary land for which a decree has been issued recognising its ownership by the Head of the Land Office of Klaten Regency, it is registered and recorded. For state land, the determination of its rights is processed by granting land rights with a Decree of the Head of the Klaten Regency Land Office.

The mechanism for determining rights in Cawas District, Klaten Regency, is as follows:

1. The administrative task force collects all administrative data relating to the application file's completeness, which has been completed with a measuring letter, announcements, checklists, and the results of a land inspection by the Juridis THE TASK FORCE.

2. The administrative THE TASK FORCE makes a collective application list, namely in the form of a list of applications for conversion/recognition of rights.

3. The administrative THE TASK FORCE submits the application lists to the Juridical THE TASK FORCE.

4. THE TASK FORCE Juridis compiles a data processing treatise and a list of requests collectively and submits it to the Education committee's head.

5. The Chair of the Education Committee shall:

a. conversion/recognition of rights if originating from customary land.

b. Proposing the granting of ownership to the Head of the Klaten Regency Land Office.

c. Chairperson of the Adj Pendidikan committee in carrying out conversion/recognition of rights.

6. The Head of the Land Office of Klaten Regency examines the application files submitted by the Chair of the Education Committee. If they meet the requirements under the applicable provisions, a Decree on the Granting of Land Rights collectively is issued submitted to the Chair of the Education Committee.

7. The Chairperson of the Education Committee shall book the rights of:

a. For customary land that has met the requirements for conversion/recognition of rights.

b. For state land that has obtained a Decree on Granting Land Rights by the Head of the Land Office of Klaten Regency.

\section{c) Issuance of Certificates}

The final stage in implementing Complete Systematic Land Registration is the issuance of land certificates. Making land title certificates through Complete Systematic Land Registration in Cawas District, Klaten Regency, is the same as making a land book. For the manufacture of a certificate, a copy of the Measurement Letter is made by the official authorised to sign the certificate concerned. Suppose the Head of the Klaten Regency Land Office is absent. In that 
case, the authority to sign the certificate may be delegated to the Head of the Land Rights and Land Registration Section with a letter of delegation of authority.

After the certificate is completed and signed, the certificate is handed over to the land titleholder in question. The submission of a Complete Systematic Land Registration certificate is carried out by the Klaten Regency Land Office in coordination with the Cawas District government of Klaten Regency. The certificate is handed over to the right holder or proxy or, in the case of the donated land being handed over to its nazir. Submission of Len's Systematic Land Registration certificate full stated in the official report of the certificate handover. Besides, before issuance, the land title certificate is examined by the Head of the Land Rights and Land Registration Section to ensure no errors and manipulation of the certificate. The handover of the land title certificate was witnessed by officials from the Cawas District, Klaten Regency. All of these procedures have been followed in the implementation of granting title to land through the National Agrarian Operation Project in Cawas District, Klaten Regency.

\section{Conclusion}

The procedure for granting title to land through Complete Systematic Land Registration in Tampan District, Klaten Regency has been carried out following existing procedures and is carried out systematically. However, there are still various obstacles in its implementation. The barriers in the performance of granting title to land in Tampan District, especially in Cawas District, Klaten Regency, are as follows:

a. It is difficult to find an object with a Tax Object Selling Value (NJOP) of not more than Rp. 30,000,000,

b. Many people cannot afford to pay fees to acquire land and building rights (BPHTB).

c. It is difficult for the applicant (people with weak economic groups) to complete the necessary documents.

d. It is difficult for the applicant to present borders (neighbours) at the time of the measurement.

\section{References}

[1] Ali Sofwan Husein, Konflik Pertanahan Dimensi Keadilan dan Kepentingan Ekonomi, Pustaka Sinar Harapan Jakarta, 1997

[2] Arie Sukanti Hutagalung dan Markus Gunawan, Kewenangan Pemerintah di Bidang Pertanahan,Rajawali Pers, Jakarta, 2008

[3] Erwiningsih, Winahyu, 2009, Hak Menguasai Negara atas Tanah, Cet Ke 1.Yogyakarta:UII.

[4] Harsono, Boedi, 1999, Hukum Agraria Indonesia: Sejarah pembentukan Undangundang Pokok Agraria, isi dan Pelaksanaannya. Ed.rev.,Cet.ke-8. Jakarta: Djambatan.

[5] ----------, 2002, Menuju Penyempurnaan Hukum Tanah Nasional dalam Hubungannya dengan TAP MPR RI IX/MPR/2001. Jakarta: Universitas Trisakti.

[6] --------, 2003, Hukum Agraria Indonesia, Sejarah Pembentukan Undang-undang Pokok Agraria Isi dan Pelaksanaannya, Edisi Revisi. Jakarta: Djambatan.

[7] Lubis, Mhd. Yamin dan Lubis, Abd.Rahim, 2008, Hukum PendaftaranTanah. Bandung: Mandar Maju. 
[8] Nolind, Indra, 2011, UUD RI 1945 \& Amandemen. Bandung: Pustaka Tanah Air.

[9] Team Nusantara, Kitab Undang-Undang Hukum Perdata, (Jakarta: Nusantara Publisher, 2009) 25.

[10] Hilman Hadikusuma, Hukum Perkawinan Indonesia Menurut; Perundangan, Hukum adat, dan Hukum, (Agama, Erlangga, Jakarta, 2003) 133.

[11] Syafran Sofyan SH, SpN, MHum," Analisis Putusan MK," http//hukum online.(diakses pada 01-08-2014).

[12] Sudarsono, Hukum Kekeluargaan Nasional (Jakarta: Rineka Cipta, 1991) 23 